\title{
Pohjoismainen tiivistelmä
}

Kokemuksia pohjoismaisesta tutkimuksesta "Improving Nordic policymaking on sustainable consumption with accessible knowledge and by dispelling myths that thwart sustainability", Policy Brief, toukokuu 2013

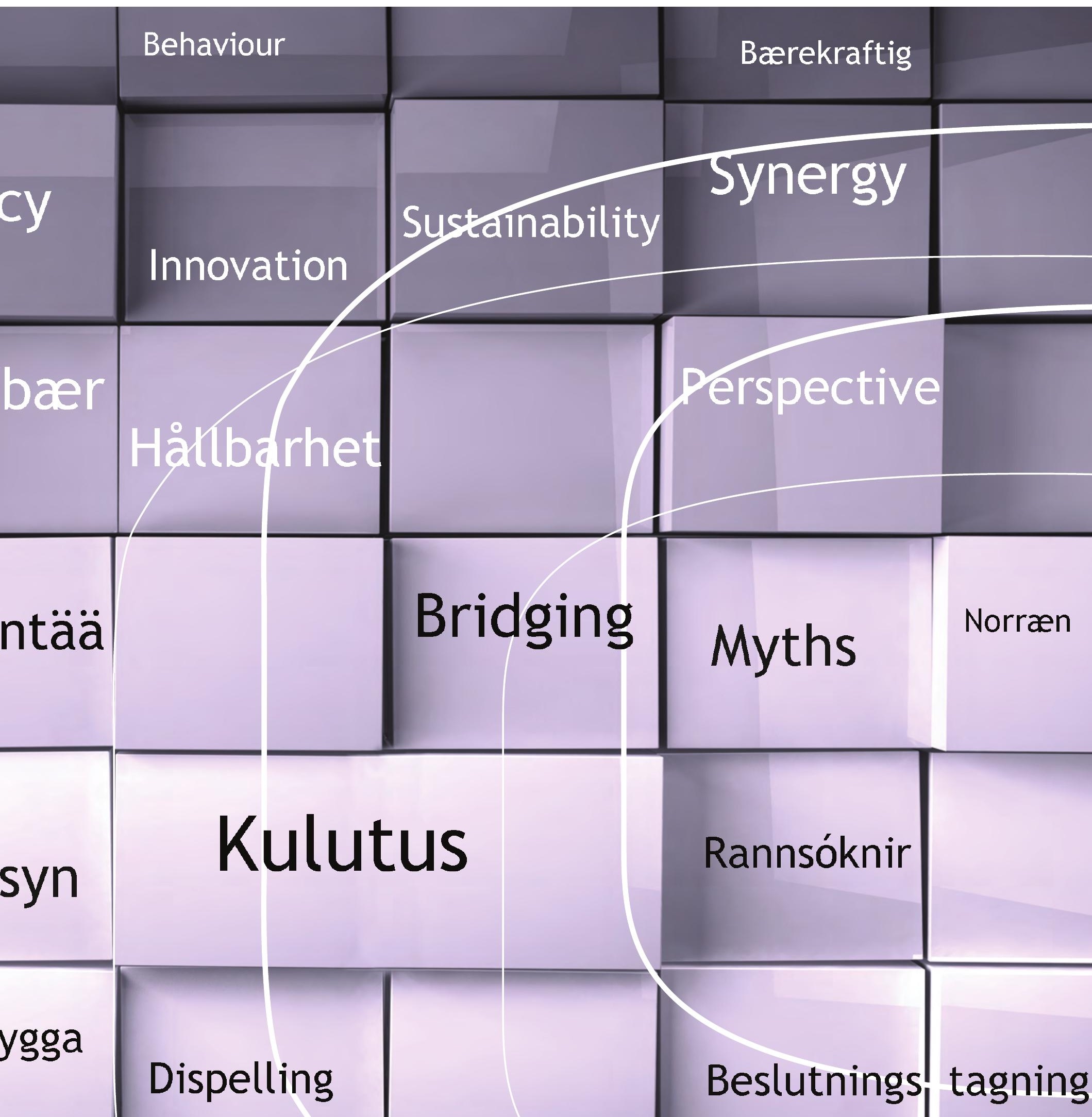



4 norden 



\section{Pohjoismainen tiivistelmä}

Kokemuksia pohjoismaisesta tutkimuksesta "Improving Nordic policymaking on sustainable consumption with accessible knowledge and by dispelling myths that thwart sustainability," Policy Brief, toukokuu 2013 
Pohjoismainen tiivistelmä

Kokemuksia pohjoismaisesta tutkimuksesta "Improving Nordic policymaking on sustainable consumption with accessible knowledge and by dispelling myths that thwart sustainability," Policy Brief, toukokuu 2013

ISBN 978-92-893-2697-1

ISBN 978-92-893-2714-5 (EPUB)

http://dx.doi.org/10.6027/TN2014-505

TemaNord 2014:505

ISSN 0908-6692

(C) Pohjoismaiden ministerineuvosto 2014

Ulkoasu: Hanne Lebech

Kannen valokuva: ImageSelect

Pohjoismaiden ministerineuvosto on myöntänyt tukea raportin julkaisemiseen. Raportin sisältö ei välttämättä edusta Pohjoismaiden ministerineuvoston kantaa, näkemyksiä tai suosituksia.

www.norden.org/fi/julkaisut

Pohjoismainen yhteistyö

Pohjoismainen yhteistyö on yksi maailman laajimpia alueellisia yhteistyömuotoja. Yhteistyön piiriin kuuluvat Islanti, Norja, Ruotsi, Suomi ja Tanska sekä Ahvenanmaa, Färsaaret ja Grönlanti.

Pohjoismaista yhteistyötä tehdään politiikan, talouden ja kulttuurin aloilla tärkeänä osana eurooppalaista ja kansainvälistä yhteistyötä. Pohjoismaisen yhteisön tavoitteena on vahva Pohjola vahvassa Euroopassa.

Pohjoismainen yhteistyö pyrkii vahvistamaan pohjoismaisia ja alueellisia etuja ja arvoja globaalissa maailmassa. Maiden yhteiset arvot lujittavat osaltaan Pohjolan asemaa yhtenä maailman innovatiivisimmista ja kilpailukykyisimmistä alueista.

Pohjoismaiden ministerineuvosto

Ved Stranden 18

DK-1061 København K

Puhelin (+45) 33960200

www.norden.org 


\section{Sisältö}

1. Johdanto

1.1 Tutkimuksen tarkoitus ........................................................................................

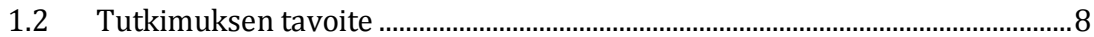

1.3 Tutkimuksen lähestymistapa ........................................................................

1.4 Keskeiset viestit päätöksentekijöille ..................................................................

2. Myyttien keskeiset opetukset.................................................................................... 11

2.1 Myytti nro 1: Vihreä kulutus tarjoaa ratkaisun ............................................... 11

2.2 Myytti nro 2: Kuluttajien tulee johtaa siirtymistä kestävyyteen................... 11

2.3 Myytti nro 3: Jos kaikki tekevät vähän, saavutamme paljon...........................12

2.4 Myytti nro 4: Pienet ja helpot ympäristötoimet laajenevat isoiksi muutoksiksi leviämisvaikutuksen ansiosta ....................................................... 13

2.5 Myytti nro 5: Paremmat tiedot johtavat kestävään käyttäytymiseen.......... 14

2.6 Myytti nro 6: Ihmisten omaan etuun vetoaminen on tie kestävään

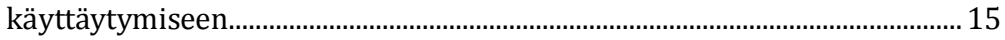

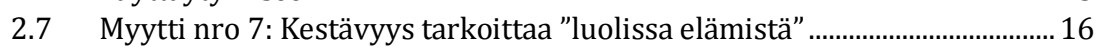

2.8 Myytti nro 8: Ihmiset ovat onnellisempia, jos heillä on enemmän rahaa ja korkeampi aineellisen kulutuksen taso.............................................. 17

2.9 Myytti nro 9: Kaikenlaisten tuotteiden yksityinen omistaminen on toivottavaa - jakaminen ei .................................................................................. 18

2.10 Myytti nro 10: Kulutuspolitiikat ovat liian kiistanalainen asia suuren yleisön hyväksyttäväksi ......................................................................... 18

3. Tiedon välittämisen keskeiset opetukset.................................................................... 21

3.1 Kuinka tutkimustuloksia käytetään päätöksenteossa..................................... 21

3.2 Riittävän tutkimuksen saatavuus kestävää kehitystä koskevaa päätöksentekoa varten .................................................................................... 22

3.3 Kestävän kulutuksen politiikan tutkimuspohja............................................... 23

3.4 Tiedon käytön esteitä ja ideoita niiden ylittämiseksi.................................. 23

4. Tutkimuksen tausta .......................................................................................................... 27

4.1 Tutkimuksen tavoite ……….......................................................................... 27

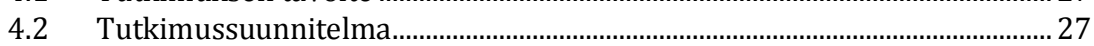

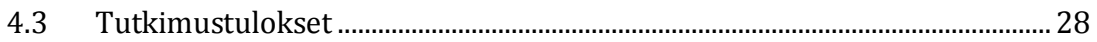

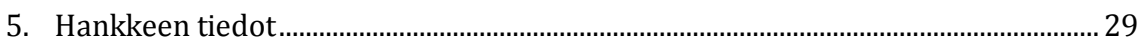





\section{Johdanto}

\subsection{Tutkimuksen tarkoitus}

Vaikka kestävän kulutuksen politiikkaa on harjoitettu 20 vuotta (UNCED 1992), materiaalien kulutus ja ympäristövaikutukset lisääntyvät edelleen Pohjoismaissa ja Euroopassa. Pohjoismaiden kunnianhimoisena tavoitteena on olla kestävän kehityksen kärjessä. Siksi julkisen vallan ohjaus pyrkii helpottamaan ja mahdollistamaan kestäviä kulutus- ja elämäntapoja, jotka ovat tärkeässä osassa pyrittäessä vähentämään luonnonvarojen käyttöä ja ympäristövaikutuksia. Nykyinen kestävän kulutuksen ohjaus ei ole kuitenkaan niin tehokasta, kuin se voisi olla.

Tämän on todettu johtuvan useista eri syistä, kuten kuluttajien itsemääräämisoikeuden periaatteesta, ohjauskeinojen puutteesta sekä siitä, ettei löydy riittävästi rohkeutta tarttua kulutuskysymyksiin. Käyttäytymis- ja yhteiskuntatieteiden tutkimustuloksia ei ole totuttu käyttämään ympäristöpolitiikassa, vaikka suuri osa ympäristövaikutuksista johtuu kulutustottumuksista.

Näin ollen kestävää kulutusta koskevaan valtavirtakeskusteluun erityisesti ohjauskeinojen valmisteluun - on juurtunut joitakin sitkeitä harhaluuloja kuluttajien käyttäytymisestä - myyttejä. Näistä myyteistä kiinni pitävät päätöksentekijät keskittyvät tuotannon ja tuotteiden tehostamista edistävään tekniseen innovointiin, jolloin sosiaalinen innovointi, vaihtoehtoiset arvonluontimallit ja kohtuullinen kulutus jäävät ilman kaivattua tukea. Päätöksentekijät eivät huomaa, kuinka monimutkainen asia kulutus todellisuudessa on ja kuinka rajallinen vaikutus monilla puolitiehen jäävillä kestävän kulutuksen politiikkatoimilla on. Tästä syystä päätöksentekijät eivät pysty tehokkaasti tarttumaan kulutukseen liittyviin kestävyyshaasteisiin. 


\subsection{Tutkimuksen tavoite}

Tämän tutkimuksen tavoitteena on kumota kestävää kehitystä estäviä myyttejä esittämällä tutkimustietoa kuluttajakäyttäytymisestä tehokkaiden kestävän kulutuksen politiikkojen kehittämiseksi Pohjoismaissa.

\subsection{Tutkimuksen lähestymistapa}

Tutkimus perustuu laajaan kansainväliseen kuluttajakäyttäytymistä koskevaan tutkimusaineistoon mm. psykologian, sosiologian, käyttäytymistalouden, politiikan ja antropologian aloilta. Tämä tieto ei ole saavuttanut suurinta osaa kestävän kulutuksen kysymyksiä käsittelevistä päätöksentekijöistä. Tutkimuksessa käytetään tiedon välittämisen (knowledge brokering) lähestymistapaa, jossa vaihdetaan ja siirretään laaja-alaista, monitieteistä akateemista ja käytännön tietoa tieteentekijöiden, päätöksentekijöiden ja käytännön toimijoiden välillä helposti käytettävässä muodossa tarkoituksena olemassa olevan tiedon hyödyntämisen edistäminen päätöksenteossa.

\subsection{Keskeiset viestit päätöksentekijöille}

On epärealistista odottaa kestävän yhteiskunnan toteutumista nykyisten kestävän kehityksen poliittisten strategioiden pohjalta. Tarvitaan isoja muutoksia, ja tässä tutkimuksessa tiivistetty tutkimustieto osoittaa, että päätöksentekijöillä on suunnaton määrä mahdollisuuksia luoda myönteisiä muutoksia hyödyntämällä strategioita ja välineitä synergistisesti.

Yhteiskuntamme perustuu kulutukseen: yhteiskunnan rakenteet edistävät kulutustottumuksia, joita Pohjoismaissa pidetään normaaleina, mutta jotka eivät ole kestäviä. Toisaalta kansalaiset, jotka yrittävät tehdä merkittäviä kestävyyttä edistäviä muutoksia elämäntapaansa, kohtaavat ylipääsemättömiä sosiokulttuurisia ja käytännön esteitä. Tämä korostaa julkishallinnon tarvetta johtaa siirtymistä kestävyyden kulttuureihin.

Hallinnon ja poliittisten päätöksentekijöiden on johdettava siirtymistä kestävyyteen kehittämällä yhteiskunnallisia rakenteita, jotka tekevät kestävästä elämisestä oletusvaihtoehdon. Tässä on yhdistettävä tekniikan ja infrastruktuurin uudistuksia, sääntelyä, hinnoittelua, markkinointia ja uusia sosiaalisia normeja luotaessa kestävien valintojen arkkitehtuuri.

Sääntely on usein tehokkain poliittinen välinen kulutustottumusten muuttamiseksi. Vaikka sääntelyn aikaansaaminen voi olla haasteelli- 
sempaa, saatavilla on tutkimustietoa käytännön tekniikoista, joilla pystytään menestyksekkäästi toteuttamaan vahvempia poliittisia toimia. Usein sääntelyn vaikutusta tehostaa sen yhdistäminen muihin politiikan instrumentteihin kuten taloudellisiin ja informatiivisiin ohjauskeinoihin niin kutsutuiksi politiikkapaketeiksi.

Myönteisten sosiaalisten normien kehittäminen on olennaista kestävien käytäntöjen juurruttamiseksi arkielämään ja kansalaisten hyväksynnän saamiseksi tiukemmille kulutuspolitiikoille. Myös pakottavia ja kieltäviä politiikkoja, jotka edellyttävät isoja elintapojen muutoksia kuten yksityisautoilun korvaamista julkisella liikenteellä, hyväksytään paremmin, kun ohjauskeino kehystetään oikealla tavalla, vahvistetaan yhteiskunta- ja ympäristömyönteisiä sosiaalisia normeja sekä tarjotaan turvallisia, mukavia ja halpoja kestäviä vaihtoehtoja kestävän kehityksen vastaisille käyttäytymismalleille.

Poliittinen painopiste on asetettava siten, että sillä edistetään siirtymistä pois merkittävän ympäristövaikutuksen aiheuttavilta kulutuksen aloilta (esim. lentomatkustus, lihan ja meijerituotteiden kulutus ja autoilu) pienemmän ympäristövaikutuksen aiheuttaville kulutuksen aloille (esim. kasvisruokavalio, julkinen liikenne, paikallinen vapaa-ajanviettoja kulttuuritarjonta sekä henkinen kasvu ja kehitys).

Kun otetaan huomioon ihmisten tarve tulla onnellisemmiksi ja terveemmiksi, tarvitaan nykyistä paljon laajempi valikoima hyvinvointiin johtavia polkuja. Voi olla hyödyllistä esittää laajempi hyvinvoinnin visio, joka sisältää yhteiskuntamyönteisiä arvoja kuten sopeutuvat yhdyskunnat ja oikeudenmukainen, reilu ja kestävä luonnonvarojen käyttö, terveys, koulutus ja henkinen kasvu, rauha ja vakaus, ympäristöllinen ja sosiaalinen oikeudenmukaisuus sekä muita suoraan yksilöihin ja perheisiin vaikuttavia makrokysymyksiä. On kehitettävä uusia yhteiskunnallisen vaurauden mittoja kestävien elintapojen tukemiseksi ja rohkaisemiseksi. 



\section{Myyttien keskeiset opetukset}

\subsection{Myytti nro 1: Vihreä kulutus tarjoaa ratkaisun}

Vihreä kulutus on yksi muttei ainoa strategia kulutuksesta johtuvan luonnonvarojen käytön ja ympäristövaikutusten vähentämiseksi.

Totuus: Vihreä kulutus on tärkeä mutta rajallinen strategia, jonka tarkoituksena on parantaa tuotantoprosessien tehokkuutta sekä suunnitella ja myydä ympäristön ja yhteiskunnan kannalta järkeviä tuotteita.

Haasteet: Tehokkuuden parantaminen on tärkeää ja sen tulee jatkua, mutta se ei riitä. Myös "vihreät" tuotteet vaikuttavat ympäristöön. Kulutuksen jatkuva kasvu kumoaa tuotannon ja tuotteiden tehokkuuden parantamisen kokonaisvaikutukset. Vihreä kulutus auttaa meitä siten hidastamaan ympäristöongelmia, mutta se ei yksin pysty estämään tai välttämään niitä.

Myytti edistää väärää optimistista näkemystä siitä, että tekniset ratkaisut riittävät kestävän kehityksen aikaansaamiseen. Se suuntaa huomion pois tarpeesta tarttua vaikeisiin kysymyksiin kuten vallitsevaan kulutuskulttuuriin sekä luonnonvarojen käyttöön liittyvään materialismiin.

Seuraukset: Kestävän kulutuksen ja kestävien elintapojen strategioiden tulee täydentää tehokkuusstrategioita. Lisäksi ne voivat sisältää sellaisia kohtuullista kulutusta edistäviä toimia kuten siirtyminen tuotteista palveluiden kulutukseen ja tuotteiden jakaminen omistamisen sijaan, sekä luovien ratkaisujen löytäminen joutilaan tavarakapasiteetin hyödyntämisessä sekä tuotteiden korjauksessa.

\subsection{Myytti nro 2: Kuluttajien tulee johtaa siirtymistä kestävyyteen}

Yksilökäyttäytymisen muutoksilla saaduilla tuloksilla on rajansa. Vallitseviin taloudellisiin instituutioihin ja liiketoimintamalleihin, sääntöihin sekä infrastruktuureihin on tehtävä systeemisiä muutoksia. Julkisen vallan on johdettava siirtymistä kestävyyteen. Yksilöillä, yrityksillä ja kansalaisyhteiskunnalla on muita tärkeitä rooleja. 
Totuus: Kuluttajilla on jossain määrin vastuuta kulutuksensa ja elintapojensa seurauksista, varsinkin kun kotitaloudet aiheuttavat $40 \%$ yhteiskunnan kokonaisympäristövaikutuksista. Mutta julkinen valta ohjaa suuria kokonaismuutoksia kulttuurissa ja kulutuksessa sekä tuotantomalleissa.

Haasteet: On väärin ajatella, että kuluttajat ohjaavat markkinoita ja yritykset pelkästään vastaavat vaatimuksiin. Sekä yritykset että päätöksentekijät ovat valinta-arkkitehteja, jotka rajaavat kuluttajien toiminnan vaihtoehdot. Vallitsevat yhteiskunnalliset arvot, käytännöt ja sosiaaliset normit ovat harjoitetun politiikan muotoilemia esim. sääntelyn, infrastruktuurin, hinnoittelumekanismin ja koulutusjärjestelmän kautta.

Seuraukset: Tämä tutkimus osoittaa, että monet sidosryhmät, mukaan lukien yritykset ja kuluttajat, odottavat johtajuutta hallituksilta ja päätöksentekijöiltä. Julkinen valta on tärkeimpiä toimijoita pyrittäessä yleisiin muutoksiin kulutuskulttuurissamme. Kansalaisilla, yrityksillä ja kansalaisyhteiskunnalla on muita tärkeitä tehtäviä.

Kestävyyteen on suhtauduttava kuten perustarpeeseen eikä kauppatavaraan. Ihmiset, jotka nyt yrittävät elää kestävän kehityksen mukaisesti, kokevat usein vaikeana elää valtavirtanormien ja -käytäntöjen vastaisesti. Jotkut käyttäytymismallit ovat infrastruktuurin rajoitteiden, hinnoittelun ja sosiaalisten konventioiden "lukitsemia." Politiikanteko on avainasemassa normalisoitaessa kestäviä elintapoja. Julkisen vallan tulee johtaa kestävien elintapojen normalisoimista.

\subsection{Myytti nro 3: Jos kaikki tekevät vähän, saavutamme paljon}

Kaikkien tulee antaa oma panoksensa kestävään kehitykseen, mutta yhteiskuntien siirtämiseksi kestävään kehitykseen tarvitaan isoja muutoksia.

Totuus: Pienet muutokset ovat tärkeä lähtökohta. Iskulause "jos kaikki..." korostaa, että jokaisen panos on arvokas ja tärkeä ja että myös muut ottavat vastuuta käyttäytymisestään ja tekevät muutoksia. Pienet muutokset ovat tärkeitä, koska ihmisten on aloitettava jostakin, tunnettava olevansa osa ryhmää ja koettava tekevänsä jotain hyvää. Käännekohdan saavuttaminen ja uuden sosiaalisen normin vakiinnuttaminen on kuitenkin huomattavan iso haaste.

Haasteet: Suurin harhaluulo on, että pienet yksittäiset muutokset johtavat merkittäviin tuloksiin, koska niiden summa johtaa yleensä vain pieniin kokonaisparannuksiin. Toinen ongelma on iskulauseen muotoilu: ihmiset tietävät, että kaikki eivät hoida osuuttaan, ja saattavat lannistua 
eivätkä ryhdy toimiin. Usein on vaikea nähdä, kuinka kotitalouden pienet toimet voivat auttaa ratkaisemaan maailmanlaajuisia ympäristöongelmia, mikä aiheuttaa skeptisyyttä. "Vapaamatkustajia" saattaa rohkaista se, että omalla passiivisuudella ei uskota olevan merkittävää vaikutusta kokonaistasoon. Näiden ongelmien lisäksi esiintyy kahdentyyppistä vastavaikutusta (rebound-ilmiöt). Käytöksessä vastavaikutus näkyy silloin, kun ihmiset kokevat pienten toimiensa (esim. paperinkeräyksen) oikeuttavan toimettomuuteen muilla aloilla, esim. käyttämään omaa autoa julkisen liikenteen sijaan. Taloudellinen vastavaikutus syntyy, kun ihmiset säästävät rahaa pyöräilemällä autolla ajamisen sijaan ja käyttävät rahan merkittäviä ympäristövaikutuksia aiheuttaviin toimintoihin kuten kaukomatkoihin.

Seuraukset: Pienillä muutoksilla ja joukkoliikkeillä on vaikutusta, mutta on tärkeää tehdä selväksi, että myös isoja muutoksia tarvitaan. Myönteinen rohkaisu ja realistisen kuvan antaminen yhteiskunnassa tarvittavan muutoksen mittakaavasta ovat myös tärkeitä. Päätöksentekijöiden ja kansalaisyhteiskunnan viestinnässä tulisi korostaa sekä yksilöiden elämässään tekemien pienten muutosten tärkeyttä että tarvittavia laajamittaisia muutoksia ja tapoja, joilla kansalaiset voivat osallistua niihin.

\subsection{Myytti nro 4: Pienet ja helpot ympäristötoimet laajenevat isoiksi muutoksiksi leviämis- vaikutuksen ansiosta}

Leviämisvaikutusta esiintyy todennäköisesti vain samanlaisten toimien välil-

lä tai samanlaisissa yhteyksissä.

Totuus: Markkinointiteoria rohkaisee meitä "aloittamaan sieltä, missä ihmiset ovat," saamaan heidät liikkeelle oikeaan suuntaan helpoilla toimilla, joiden pitäisi teoreettisesti helpottaa siirtymistä seuraavalle käyttäytymismuutoksen tasolle. Tutkimus osoittaa, että positiivista leviämisvaikutusta esiintyy samanlaisten toimien välillä, esim. kierrätys työpaikalla voi kannustaa kierrätykseen kotona tai ympäristömerkittyjen tuotteiden ostaminen johtaa Reilun kaupan tuotteiden ostamiseen.

Haasteet: Positiivinen leviämisvaikutus ei todennäköisesti johda isompiin muutoksiin. Esimerkiksi pienet toimet kuten kierrätys eivät yleensä laajene isoiksi elintapojen muutoksiksi, joita tarvittaisiin. Näitä ovat esimerkiksi yksityisautoilusta luopuminen.

Seuraukset: Leviämisvaikutus onnistuu paremmin, kun ihmiset tekevät pieniä toimia ja sitten tunnistavat itsessään henkilön, joka välittää 
ympäristöstä. Tätä voidaan rohkaista muotoilemalla toimet pikemminkin "ympäristö- ja yhteiskuntamyönteisiksi" kuin pelkästään "rahansäästöksi." Muutokseen voidaan kannustaa vaikutusmahdollisuuksia lisäävillä yhteisön aloitteilla.

On tärkeää rohkaista ihmisiä helppoihin ympäristömyönteisiin toimiin heidän oman ympäristövaikutuksensa pienentämiseksi, mutta on ratkaisevan tärkeää ymmärtää, että elintapoihin tuskin tulee isoja muutoksia sen sivuvaikutuksena. Merkittäviä elintapojen muutoksia on kannustettava, tuettava ja helpotettava kestävää infrastruktuuria edistävillä politiikoilla, hinnoittelumekanismilla ja kestävillä markkinointiviesteillä.

\subsection{Myytti nro 5: Paremmat tiedot johtavat kestävään käyttäytymiseen}

Tieto ei pysty yleensä yksin muuttamaan käyttäytymistä, mutta se on elintärkeä osa politiikkapakettia.

Totuus: Tietoisuuden lisääminen ja tiedon antaminen ovat tärkeä osa siirtymistä kohti kestävää yhteiskuntaa. Tiedottaminen on hyödyllinen osa politiikkapakettia, mutta yksin se johtaa harvoin käyttäytymisen muutoksiin.

Haasteet: Ihmiset eivät aina ole "rationaalisia hyödyn maksimoijia," joilla on käytössään tietoa, kykyä ja aikaa harkita päätöstensä ja toimiensa plussia ja miinuksia. Tiedon ja tietoisuuden lisäksi kuluttajakäyttäytymistä ohjaavat monet erilaiset tekijät infrastruktuurista, instituutioista, markkinoinnista ja hinnoittelusta tunteisiin, tapoihin ja normeihin. Käyttäytymisen muutokset ovat epätodennäköisiä, jos eri toimijat lähettävät vastakkaisia viestejä, esimerkiksi ihmisten tulee elää kestävää elämää, mutta myös "kuluttaa, jotta taloutemme nousisi finanssikriisistä." On myös haasteellista kannustaa kestävää käyttäytymistä julkisilla tiedotuskampanjoilla, jotka kilpailevat kaupallisen markkinoinnin ja mainosten kanssa mediassa, julkisissa tiloissa ja internetissä.

Seuraukset: Kestävää käyttäytymistä on edistettävä yhdenmukaisilla viesteillä, joita ei välitetä pelkästään tiedotuksen kautta vaan myös muiden strategioiden kuten infrastruktuurin, markkinoinnin, hinnoittelun ja yhteiskunnallisten instituutioiden välityksellä. Ympäristöongelmista on tiedotettava siten, että kannustetaan ihmisiä passiivisuuden sijasta toimintaan.

Tieto voi vaikuttaa käyttäytymiseen, mutta tavallisesti vain silloin, kun samanaikaisesti on käytössä vahvoja välineitä kuten sääntely ja hinnoittelu. Lisäksi asenteen ja käyttäytymisen välisestä kuilusta johtu- 
en saadaan joskus parempia tuloksia, jos tiedottamisen lisäksi ihmisille annetaan mahdollisuus kokeilla käyttäytymistä. Asenteen muutos tulee sitten, kun käyttäytyminen on vakiintunut.

\subsection{Myytti nro 6: Ihmisten omaan etuun vetoaminen on tie kestävään käyttäytymiseen}

Oman edun ja yhteiskuntamyönteisten arvojen välinen tasapaino on tarpeen

sekä lyhyen aikavälin hyödyn että pitkän aikavälin tulosten saamiseksi.

Totuus: Omaan etuun vetoaminen kuten ympäristötoimien edistäminen rahansäästötapana toimii joskus hyvin lyhyellä aikavälillä ja tietyille käyttäytymismalleille, jotka on helppo linkittää henkilökohtaisen hyödyn lisäämiseen. Sen sijaan omaan etuun vetoaminen materialistisessa mielessä saattaa päinvastoin heikentää tilannetta pitkällä aikavälillä.

Haasteet: Kestävyyden myyminen oman edun kautta saattaa kostautua, kun tarvitaan muutoksia, jotka eivät tarjoa mitään välitöntä henkilökohtaista hyötyä. Myös tulevien sukupolvien etua voi olla vaikea turvata yhteiskunnassa, joka propagoi välittömiä voittoja ja palkitsee säälimätöntä kilpailua ympäristön ja sosiaalisen tasa-arvon kustannuksella.

Seuraukset: Päätöksentekijöiden tulisi välttää ristiriitaisten viestien antamista kansalaisille ja olla korostamatta välittömiä henkilökohtaisia voittoja yhteiskunnallisten arvojen ollessa kyseessä. Yhteiskuntamyönteisten arvojen korostaminen saa ihmiset todennäköisesti ajattelemaan enemmän koko yhteisön parasta, mikä voi parantaa sekä kestävien kulutuspolitiikkojen hyväksyntää että niiden tehokkuutta.

Yksi mahdollinen ratkaisu on laajentaa oman edun käsitettä kattamaan perheen ja ystävien kanssa vietetty aika, terveyttä edistävä toiminta sekä yhteiskunnallinen osallistuminen. Myös sosiaalinen status voidaan linkittää ympäristötietoiseen kuluttamiseen tai vapaaehtoisesti yksinkertaiseen elämään eikä välttämättä stressaavaan, korkeapalkkaiseen ja merkittäviä ympäristövaikutuksia aiheuttavaan urakeskeiseen elämään. Reilun ja tasa-arvoisen kestävän yhteiskunnan turvaamiseksi meidän on tasapainotettava keskenään kysymykset "Mitä tämä antaa minulle?" ja "Mitä tämä antaa meille?". 


\subsection{Myytti nro 7: Kestävyys tarkoittaa "luolissa elämistä"}

Esimerkkejä kestävästä elämästä on jo saatu. Tarvitsemme suunniteltua siirtymistä kestäviin elintapoihin välttääksemme elintason laskun tulevaisuudessa.

Totuus: Tutkimus osoittaa, että kohtuullinen osuus kasvihuonekaasupäästöjä olisi noin 2 tonnia hiilidioksidia henkeä kohti vuodessa. Se merkitsee paljon alempia materiaalisen kulutuksen tasoja Pohjoismaille, joiden päästötaso on nyt 6-9 tonnia hiilidioksidia per henkilö.

Haasteet: On utopistista ajatella, että voimme jatkaa entiseen tapaan, mutta vaihtoehto eli kestävä elämä on kuvattu kovaksi elämäksi, joka johtaa ikävystyttävään ja epämukavaan elintapaan, hurskauteen, uhrausten tekemiseen ja hyvinvointitason alenemiseen. Tämä näkökulma vaikeuttaa kestävien elintapojen edistämistä ja hyväksynnän saamista sekä kansalaisten sitouttamista. Se heikentää myös mahdollisuutta edistää tuotteiden yhteiskäyttöjärjestelmiä tai suljetun kierron järjestelmiä, jotka voisivat vähentää kulutukseen liittyvää kokonaisvaltaista luonnonvarojen käyttöä ja ympäristövaikutusta hyvinvointia heikentämättä.

Seuraukset: Esimerkkejä kestävästä elämästä on jo saatu. Tarvitsemme suunniteltua siirtymistä kestäviin elintapoihin välttääksemme elintason laskun tulevaisuudessa.

Tarvitaan parempaa ymmärrystä siitä, millaista hyötyä vähäisiä ympäristövaikutuksia aiheuttavat elämäntavat tuovat yhteiskunnalle, yksilöiden hyvinvoinnille ja ympäristölle. Näitä etuja tulee suositella käyttäen mittana hyvää terveyttä ja elämänlaatua sekä riittävää materiaalista kulutusta eikä pelkkää aineellista yltäkylläisyyttä. On myös tiedotettava paremmin toimimattomuuden seurauksista, mieluummin pragmaattisesti kuin dramaattisesti, ja osoitettava, että vitkastelu johtaa jo nyt ympäristöongelmiin (onneksi ei vielä niin näkyvästi Pohjoismaissa) sekä heikentää elintasoa monissa Euroopan maissa.

Innovatiiviset, arvonluontia tuottavat liiketoimintamallit kuten palveluistaminen (servicizing) auttavat ymmärtämään kestävän elämän tarpeita paremmin. Tarvitaan sekä julkisen vallan että yritysten tukea kasvavalle yksilöiden, kuntien ja kaupunkien joukolle kestävämpien elintapojen mahdollistamiseksi sosiaalisten innovaatioiden kuten vähähiilisten yhdyskuntien ja yhteiskäytön avulla. 


\subsection{Myytti nro 8: Ihmiset ovat onnellisempia, jos heillä on enemmän rahaa ja korkeampi aineellisen kulutuksen taso}

Pohjoismaissa bruttokansantuotteen kasvu liitetään marginaalisiin parannuksiin hyvinvoinnissa. Sen vuoksi tarvitaan uusia indikaattoreita yhteiskunnallisen edistyksen mittaamiseen.

Totuus: Yhteiskunnissamme vallitsee vankka uskomus siitä, että tulemme onnellisemmiksi ja hyvinvointimme lisääntyy, kun ansaitsemme enemmän rahaa ja omistamme enemmän tavaroita. Tutkimusten mukaan bruttokansantuotteen kasvu liittyy tiiviisti subjektiivisen hyvinvoinnin lisääntymiseen tiettyyn pisteeseen asti. Tietyn kynnyksen yläpuolella bruttokansantuotteen kasvu alentaa hyvinvoinnin paranemisen marginaalitasoja.

Haaste: Yksilöllisiin hyvinvoinnin tasoihin vaikuttaa enemmän vauraus muihin yhteiskunnan jäseniin verrattuna kuin absoluuttiset vauraustasot. Jotkut tutkimukset osoittavat myös, että on mahdollista saavuttaa korkeampia hyvinvoinnin tasoja alhaisemmilla aineellisen kulutuksen tasoilla, kun tietty aineellinen taso on saavutettu.

Ihmiset tavoittelevat korkeampia tuloja ja aineellisen kulutuksen tasoja yrittäessään lisätä henkilökohtaista onnellisuuttaan, vaikka he joutuisivat sen takia joskus tekemään uhrauksia terveyden, vapaa-ajan sekä perhe- ja yhteiskunnallisen elämän suhteen. Toisaalta ihmiset, jotka vapaaehtoisesti päättävät työskennellä ja kuluttaa vähemmän, ilmoittavat usein hyvinvointinsa ja tyytyväisyytensä elämään lisääntyneen.

Seuraukset: Poliitikot pelkäävät etäännyttävänsä kansalaiset kulutustottumuksiin ja -tasoihin puuttuvilla politiikoilla. Ehkä politiikat ja toimet voisi muotoilla siten, että ne edistävät kestäviä elämäntapoja, jolloin huomion keskittäminen aineellisen kulutuksen tasoihin olisi vähemmän dramaattista ja yhteiskuntakeskustelu voisi siirtyä ennakoivammalle ja tuottavammalle raiteelle, kuten tapoihin parantaa ihmisten elämänlaatua. Ihmisten tarvetta tulla onnellisemmiksi ymmärretään ja tuetaan, ja siksi on syytä keskustella nykyistä paljon laajemmasta valikoimasta onneen johtavia polkuja. On mahdollista hyödyntää esim. teknisen kehityksen hyödyt ei pelkästään rahallisessa mielessä vaan myös mielekkään vapaa-ajan vieton ja henkilökohtaisen kehityksen kannalta.

On kehitettävä uusia yhteiskunnallisen vaurauden mittoja kestävien elintapojen tukemiseksi ja rohkaisemiseksi. Esimerkkinä mainittakoon bruttokansantuotteen vaihtoehtoiset indikaattorit, jotka WAVES World Bank programme ja Beyond Growth Movement ovat kehittäneet. 


\subsection{Myytti nro 9: Kaikenlaisten tuotteiden yksityinen omistaminen on toivottavaa - jakaminen ei}

Kaikenlaisten tuotteiden jakamistalous ja yhteiskulutus on elpymässä. Päätöksentekijät voivat auttaa vähentämällä jakamis- ja yhteistalouden esteitä sekä tukemalla sen vaikutuksista tarvittavaa tutkimusta.

Totuus: Yhteiskuntamme perustuu omistamisen instituutioon. Jakaminen ei kiinnosta, jos jakamisen kustannukset sekä rahallisesti että jakamisen hallinnointiin käytetyn ajan puitteissa ovat korkeammat kuin omistamisen kustannukset.

Haasteet: Monet ihmiset ovat huolissaan kasvavasta määrästä tuotteita, jotka vievät tilaa heidän kodeissaan ja joiden huoltaminen vie aikaa. Yhä useampia käyttökelpoisia tuotteita korvataan uusilla, ja kertakäyttötuotteiden kulutus jatkaa kasvuaan.

Vaikka tuotteiden omistaminen lisääntyy, kaikenlaisten tuotteiden yhteiskulutus on myös elpymässä. Esimerkkejä tästä ovat tavaravaihtotapahtumat, käytettyjen tavaroiden internet-kauppa, laitteita lainaavat kirjastot ja kaupunkien auton- ja pyöränvuokrausjärjestelmät. Pohjoismaissa on useita perinteisiä tuotteiden yhteiskäyttöjärjestelmiä, kuten yleiset kirjastot ja talopesulat, ja niitä on mahdollista vielä lisätä ja parantaa uusilla innovatiivisilla yhteiskulutuksen muodoilla.

Seuraukset: Monet innovatiiviset uudet yritykset osoittavat, että nykyisten luonnonvarojen ja tuotteiden yhteiseen käyttämiseen ja uudelleen jakamiseen on potentiaalia. Tuotteiden uusiokäyttö auttaa välttämään ympäristövaikutuksia, jotka liittyvät uusien tuotteiden valmistukseen, ja "urbaani kaivostoiminta" on tärkeä materiaalien lähde tulevaisuudessa. Jakamistaloutta voidaan tukea virallisilla ja epävirallisilla aloitteilla, joiden tavoitteena on tavaroiden ja palveluiden lainaaminen, vaihtaminen, vaihtokauppa tai vuokraaminen yksityisomistuksen sijaan.

\subsection{Myytti nro 10: Kulutuspolitiikat ovat liian kiistanalainen asia suuren yleisön hyväksyttäväksi}

Politiikka ei ole koskaan neutraalia, vaan se muodostaa sosiaalisia normeja ja arvoja yhteiskuntaan. Päätöksentekijöiden on syytä luoda kestävyyteen suuntaava "mahdollisuuksien politiikka" hyödyntämällä synergistisesti suurta määrää olemassa olevia ja uusia strategioita. 
Totuus: Kulutukseen keskittyvillä kestävyyspolitiikoilla ei ole yhtä pitkää historiaa kuin monilla muilla ympäristöpolitiikan aloilla. Kulutus nähdään usein osana elämän yksityisaluetta, johon poliitikkojen ei tulisi puuttua. Kuluttajien oletetaan olevan täysivaltaisia, toisin sanoen he voivat vapaasti tehdä markkinoilla valintoja, jotka heijastelevat heidän mieltymyksiään. Näin ollen monet päätöksentekijät pitävät kestävän kulutuksen politiikkaa liian kiistanalaisena, vaikka vahva yleinen etu puoltaisikin kulutustottumuksiin vaikuttamista.

Haasteet: Kaikki politiikat sisältävät arvolatauksia. Monet nykyisistä politiikoista vaikuttavat jo yksilöllisiin elintapoihimme ja kulutukseen, mutta olemme niin tottuneita niihin, että ne ovat "näkymättömiä" (esim. auton ajokielto alkoholin vaikutuksen alaisena, turvavyön käyttö jne.). Kulutuksen sääntely on ollut tehokasta jopa silloin, kun se alussa tuntui liian kiistanalaiselta, kuten esimerkiksi ravintoloiden tupakointikielto, ruuhkamaksut tai tehottomien hehkulamppujen poistaminen markkinoilta.

Seuraukset: Vaikka asioihin puuttumiseen ja holhoamiseen suhtaudutaankin haluttomasti, politiikka ei ole koskaan neutraalia, vaan se muodostaa sosiaalisia normeja ja arvoja yhteiskuntaan. Esimerkiksi tiukat kasvihuonekaasujen päästötavoitteet kertovat kansalaisille, että ympäristökysymykset on syytä ottaa vakavasti.

Useiden strategioiden tiedetään parantavan kestävän kulutuksen politiikkojen hyväksyntää, esimerkiksi positiivisten sosiaalisten normien kehittäminen vahvojen poliittisten interventioiden tukemiseksi, kansalaisten mahdollisuus kokeilla ja saada kokemusta uusista kulutustavoista, kansalaisten osallistuminen päätöksentekoon, näkyvien positiivisten vaikutusten saavuttaminen ja asenteiden sopeuttaminen heti, kun toimi on normalisoitunut. Siten tapa, jolla politiikasta tiedotetaan ja sitä toteutetaan, voi lisätä huomattavasti suuren yleisön hyväksyntää jopa haastavampien käyttäytymismallien ja kieltävien politiikkojen osalta.

Pohjoismaisia poliitikkoja voisi inspiroida J. F. Kennedyn päätös lähettää ihminen kuuhun, mitä pilkattiin "mahdottomaksi" Kennedyn ilmoittaessa asiasta ensimmäisen kerran. Toteuttaakseen mahdottoman hän loi mahdollisuuden kulttuurin, joka tuki aiemmin käsittämättömiä ja ennalta arvaamattomia teknisiä läpimurtoja. Ihmisen lähettäminen kuuhun merkitsi systeemisiä ja visionäärisiä muutoksia, jotka edellyttivät monien ministeriöiden ja eri sektoreiden tukea. Kaikki toimijat hyödynsivät syvälle juurtuneita kulttuuriarvoja luodakseen "mahdollisuuden politiikkoja." 



\section{Tiedon välittämisen keskeiset opetukset}

Pääasiallisena esteenä tutkimustietoon perustuvalle päätöksenteolle kestävästä kehityksestä ovat vallitsevat harhaluulot, yksinkertaistukset ja yleistykset kuluttajakäyttäytymisestä - joita kutsumme tässä myyteiksi. Asiaa monimutkaistaa se, että kaikki myytit sisältävät jonkin verran totuutta. Tärkeintä on siten löytää ja esittää saatavilla olevaa tutkimustietoa objektiivisesti ja tasapuolisesti. Toinen ongelma on se, että kuluttajakäyttäytymistä koskeva tutkimus on todella monimutkaista ja sitä voi olla vaikea hyödyntää politiikan maailmassa, varsinkin kun suurin osa kestävän kulutuksen politiikkaa laativista päätöksentekijöistä tulee talouselämän, tekniikan, juridiikan tai luonnontieteiden alalta käyttäytymistieteiden ollessa aliedustettuja. Kyseisen lukkiutuneen rakenteen johdosta käyttäytymistieteiden tutkimustietoa ei hyödynnetä riittävästi.

Tässä tutkimuksessa uskaltauduttiin tarkastelemaan valtavan laajaa, monitieteistä kuluttajakäyttäytymistä koskevaa tietoaineistoa sekä keräämään ja esittelemään tutkimustietoa edellä mainituista harhaluuloista. Lisäksi tutkimuksessa tunnistettiin nykyiseen tiedon välittämiseen liittyviä esteitä ja hahmoteltiin parhaita tapoja esitellä, jakaa ja vaihtaa tietoa paremmin. Näkemykset koottiin haastattelemalla pohjoismaisia päätöksentekijöitä. Tarkoituksena on vähentää esteitä tehokkaan kestävän kulutuspolitiikan suunnittelun ja toteutuksen tieltä.

\subsection{Kuinka tutkimustuloksia käytetään päätöksenteossa}

Aika on tärkein rajoite, kun on kysymys Pohjoismaisten poliittisten päätöksentekijöiden mahdollisuuksista hyödyntää tutkimustuloksia. Tämä viittaa tarpeeseen saada syntetisoitua tietoa, joka on yksinkertaistettua ja jota pidetään hyödyllisenä päätöksenteossa. Tutkijoiden ja päätöksentekijöiden tiedon tarve on usein hyvin erilainen. Tutkijat pyrkivät haastamaan senhetkisiä näkemyksiä ja luomaan uutta tietoa, päätöksentekijät hakevat helposti käytettävää ja selkeitä ratkaisuja tarjoavaa tietoa. 
Päätöksenteko ei myöskään ole pelkästään tutkimustiedon soveltamisprosessi, vaan monimutkainen poliittinen prosessi. Sen vuoksi tutkimuksen täytyy vakuuttaa ei pelkästään virkamiehet vaan myös poliitikot ja heidän äänestäjänsä. Tämä mainittiin usein yhtenä avainalueena, jolla tutkimuksen tekeminen ei täytä sille asetettuja odotuksia. Monet haastatellut korostivat, että yhteiskunnallisen ja poliittisen konsensuksen puute oli usein esteenä uuden tiedon soveltamiselle.

Useimmat haastatelluista huomauttivat, että oikeustiede ja taloustiede ovat kaksi tutkimusalaa, joiden käyttö on vakiintunut päätöksenteossa. Ympäristöpolitiikassa hyödynnetään usein myös luonnontieteitä ja teknisiä tieteitä, joita pidettiin tärkeinä myös kestävän kulutuksen politiikkoja suunniteltaessa. Suurimmat ongelmat tiedon integroinnissa koskivat yhteiskuntatieteitä, jotka eivät useinkaan ole kumulatiivisia tai kontekstista riippumattomia samalla tavalla kuin luonnontieteet. Kuluttajakäyttäytyminen koostuu erityyppisistä käyttäytymisistä, jotka esiintyvät erityyppisissä konteksteissa, joten ei ole olemassa mitään hienoja teorioita tai tiukkoja lakeja, joihin voisi turvautua.

Monet haastatelluista korostivat, että tarvitaan enemmän monitieteistä tutkimusta. Tutkimusta tarvitaan tehokkaista keinoista kulutuskäyttäytymisen muuttamiseksi. Lisäksi tarvitaan tutkimusta yleisen kulutuspolitiikan asemasta yhteiskunnassa kuten kulutuksen yhteyksistä onnellisuuteen ja hyvinvointiin.

\subsection{Riittävän tutkimuksen saatavuus kestävää kulutusta koskevaa päätöksentekoa varten}

Pohjoismaisten päätöksentekijöiden tunnistamat tärkeimmät tietovajeet ovat lyhyesti seuraavat:

- Tuloksettomuus: tutkimus ei ole vakuuttavaa, se on ristiriitaista ja esittää kulutuskäyttäytymisen hämmentävässä valossa.

- Monimutkaisuus: tietoa ei ole kerätty ja esitetty helposti ymmärrettävässä muodossa, minkä johdosta se jää näkymättömäksi eikä tule päätöksentekijöiden käyttöön.

- Nopea saatavuus puuttuu: Monet haastatelluista kokivat, että on vaikeaa saada nopeasti käsiinsä tietoa silloin, kun sitä tarvitsee.

- Soveltavan tutkimuksen ja politiikan arvioinnin puute: Useimmat haastatelluista korostivat, että näyttöä politiikan tehokkuudesta on saatavilla rajallisesti. Tämä johtuu osaksi puuttuvasta politiikan 
seurannasta ja arvioinnista, mutta myös puuttuvista vakiintuneista menetelmistä arvioida politiikan välineiden ja toimien tehokkuutta.

- Maakohtaisen tutkimuksen puute: Tämä ongelma koskee enemmän joitakin tiettyjä maita. Konteksti vaikuttaa selvästi poliittisten toimien tehokkuuteen ja tarvitaan tutkimuksia, joilla testataan poliittisten toimien soveltuvuutta eri maissa ja eri asiayhteyksissä.

- Kohdennetun tutkimuksen puute: Koska kestävän kulutuksen politiikka on suhteellisen uusi politiikan ala, on vaikea tunnistaa, mikä tutkimus on tärkeää ja kuinka nykyistä tutkimusta pitäisi yhdistää optimaalisesti päätöksenteon tarpeita ajatellen. Mitä laajempia yhteiskunnallisia ongelmia käsitellään, sitä suurempi on tarve kytkeä mukaan useiden alojen tutkimusta, vaikka tutkimusrahoitus ei aina tue monitieteistä tutkimusta.

\subsection{Kestävän kulutuksen politiikan tutkimuspohja}

Useimmat haastatelluista kokivat, että tietoa ei ole riittävästi näyttöön perustuvaan päätöksentekoon eikä interventioita arvioida kunnolla. He korostivat tarvetta vaikuttavuustutkimusten lisäämiseen siten, että politiikka voisi perustua tieteelliseen näyttöön.

Tutkimustietoa puuttuu eniten taloudellisten vaikutusten osalta sekä tehokkaista tavoista saada aikaan muutoksia kuluttajakäyttäytymiseen. Usein ajan ja rahan puute on syynä siihen, ettei politiikkoja testata, seurata tai arvioida eikä harvoja saatavilla olevia tutkimuksia käytetä. Tutkimuspohja on kuitenkin joillakin aloilla vankempi kuin toisilla. Esimerkiksi Pohjoismaisen ympäristömerkin, Joutsenmerkin, tunnistamiseen ja siihen kohdistuvaan luottamukseen liittyvää tutkimustietoa on suhteellisen paljon muihin ohjauskeinoihin verrattuna.

Lisäksi jotkut haastatelluista kokivat, että tutkimuspohjan puuttuminen ei sellaisenaan ole suurin ongelma. He korostivat pikemminkin politiikan roolia päätöksenteossa sekä kestävän kulutuspolitiikan vastavoimia kuten lobbausryhmiä.

\subsection{Tiedon käytön esteitä ja ideoita niiden ylittämiseksi}

Pohjoismaiset haastateltavat olivat tunnistaneet kaksi pääasiallista esteryhmää: ideologiset/poliittiset ja käytännön esteet. He korostivat politiikan roolin tärkeyttä päätöksenteossa, koska eri poliittisilla puolueilla, 
ministeriöillä ja virastoilla on eri prioriteetit (esim. työpaikkojen luominen tai verotulot). Pääesteet juontavat kuitenkin poliittisten tekijöiden ja käytännön politiikkatyön yhdistelmästä. Pohjoismaiset päätöksentekijät ehdottivat myös, että parempi tietopohja ja erityisesti parempi käytäntö hyödyntää tietopohjaa poliittisissa keskusteluprosesseissa voi osaltaan ratkaista ideologisia ja poliittisia ongelmia. He esittivät myös joitakin ideoita esteiden voittamiseksi.

Monet peräänkuuluttivat yhteistyön lisäämistä ministeriöiden välillä. Tätä pidettiin erityisen tärkeänä, koska eri sektorit hallinnoivat eri ohjauskeinoja, joten tehokkaita ohjauskein oyhdistelmiä on vaikea suunnitella. Tietyt kulutuksen näkökulmat (kuten asuminen) hoituvat ehkä paremmin nykyisillä hallintorakenteilla kuin jotkut muut. Politiikan koordinoinnin puute ja eri suuntiin vetäminen vaikeuttaa päätöksentekoa.

Poliittisesta johtajuudesta todettiin, että tutkijoiden pitäisi välittää tietoa suoremmin poliitikoille ja suurelle yleisölle: virkamiehet eivät voi mennä poliittisen prosessin edelle, vaan he saavat poliitikoilta valtuudet politiikan laadintaan. Tutkijat voisivat toisaalta korostaa kuluttajien itsemääräämisoikeuden rajallisuutta ja sitä, että kansalaiset kyllä arvostavat poliittista johtajuutta. Jotkut haastateltavat huomauttivat kuitenkin, että tutkijoiden suurelle yleisölle välittämät tulokset ovat usein ristiriitaisia eivätkä ne siten edistä poliittista johtajuutta kestävän kulutuksen alalla.

Tämän tutkimuksen osana järjestetyistä webinaareista saatiin myönteisiä kommentteja osanottajilta. Todettiin, että ne voisivat olla hyvä malli tutkijoiden, päätöksentekijöiden ja muiden sidosryhmien välisille keskusteluille tulevaisuudessa. Osanottajat arvostivat "innovatiivista ajatustenvaihtotapaa," mahdollisuutta solmia yhteyksiä uusiin ja vanhoihin kollegoihin, mahdollisuutta päivittää tietojaan ja saada lopulliset tulokset tutkimuksesta, johon he olivat antaneet oman panoksensa webinaareissa. Tämä saattaa lisätä halukkuutta hyödyntää tutkimustuloksia.

Tutkimus vahvisti sen, että suuri osa kuluttajakäyttäytymistä koskevasta nykyisestä tietoaineistosta on monimutkaista, nyansoitua ja kontekstisidonnaista. Tämä viittaa siihen, että tarvitaan uusia tiedon välittämisen instituutioita.

- Tiedon välittämisen keskus, esim. Pohjoismaiden ministerineuvoston isännöimä keskus, jonka tehtävänä olisi etsiä relevantteja tutkimuksia luotettavista lähteistä, arvioida tieteellisen tiedon laatua ja välittää ajantasaista tietoa kansallisille hallituksille. 
- "Konsensuspaneeli", jossa tutkijat syntetisoivat ja esittelevät kulutustutkimuksen tärkeimpiä tuloksia vähän samaan tapaan kuin Kansainvälinen ilmastonmuutospaneeli (IPCC).

- Ajatushautomo tai foorumi, jossa tiedeyhteisö ja kuluttajajärjestöt kohtaavat. Tällainen foorumi voisi perustua niin kutsuttuun pohjoismaiseen malliin olennaisesti kuuluville solidaarisuuden ja sosiaalisen demokratian arvoille, ja se selvittäisi globaalia näkökulmaa keskustelemalla kulutuksen seurauksista ei pelkästään pohjoismaiden kesken vaan myös Pohjoismaiden ulkopuolella.

Tutkimustulosten esittämistä koskevissa käytännön ehdotuksissa vaadittiin yksinkertaisia selityksiä monimutkaisille asioille helposti käytettävässä muodossa, kuvia ja kaavioita, hyviä 2-4 sivun pituisia yhteenvetoja ja selkeitä johtopäätöksiä. Tutkimustulokset pitäisi esittää vakuuttavasti ja lyhyesti kuten yritysten lobbarit tekevät Euroopan komissiossa. 



\section{Tutkimuksen tausta}

\subsection{Tutkimuksen tavoite}

Tutkimuksen erityistavoitteena on parantaa pohjoismaisten päätöksentekijöiden tietoa:

- kuluttajakäyttäytymistä koskevista keskeisistä myyteistä, jotka estävät tehokkaan päätöksenteon kestävästä kulutuksesta

- kuluttajakäyttäytymistä ja kulutusta koskevan monitieteisen tutkimuksen keskeisistä opetuksista

- saadun uuden tiedon seuraamuksista politiikkavaikutuksille.

\subsection{Tutkimussuunnitelma}

Tämä on 1-vuotinen tiedon välittämistä koskeva tutkimus, joka sisälsi neljä vaihetta:

Vaihe 1: Kirjallisuuskatsaus sisälsi olemassa olevan tietoaineiston kirjallisuuskatsauksen ja meta-analyysin kunkin myytin osalta seuraavan rakenteen mukaan: 1) alkuperä; 2) seuraukset yhteiskunnalle, kulutustottumuksille ja -tasoille, toimijoille ja poliittisille toimille; 3) perustelut, näyttö ja tietoa, joiden perusteella kukin myytti kumotaan; ja 4) seuraamukset nykyisille ja tuleville politiikkastrategioille.

Vaihe 2: Empiirinen tutkimus sisälsi tiedonkeruun puolistrukturoidulla haastattelulla, jossa haastateltiin 22 pohjoismaista päätöksentekijää ja asiantuntijaa kuluttajakäyttäytymisen myyteistä ja niiden seurauksista kestävää kulutusta edistävän politiikan laadinnalle. Lisäksi suoritettiin kaksi ryhmähaastattelua, joista toiseen osallistui 10 kestävyysalan tutkijaa ja toiseen 8 kansalaista, jotka ovat Ruotsin kestävyyspsykologian liiton jäseniä.

Vaihe 3: Analyysi ja synteesi yhdistivät akateemisen tutkimuksen tulokset päätöksentekijöiden todellisiin kokemuksiin kestävän kulutuksen alalta. Siinä arvioidaan kattavasti kysymyksiä, jotka ovat tärkeitä kestävää kehitystä koskevassa päätöksenteossa.

Vaihe 4: Tulosten levittäminen ja viimeistely mukaan lukien palautteen pyytäminen kohderyhmältä - ensisijaisesti pohjoismaisilta päätök- 
sentekijöiltä - webinaarin välityksellä. Toinen webinaari järjestettiin tarkoituksena testata tiedon ja tulosten saatavuutta ryhmälle, joka koostui kestävän kulutuksen ja tuotannon tutkijoista ja käytännön toimijoista, kansalaisyhteiskunnan asiantuntijoista sekä eurooppalaisista ja yhdysvaltalaisista opiskelijoista. Toisessa webinaarissa saatiin lisäksi palautetta joistakin enemmän nyansoiduista ja kiistanalaisista kysymyksistä sekä lisävahvistusta ja perusteluita tutkimuksen lopullisille tuloksille. Webinaareihin osallistui yhteensä 68 henkilöä.

\subsection{Tutkimustulokset}

1. Loppuraportti on luettavissa ruotsiksi ja englanniksi osoitteessa http://www.norden.org/en/publications/publikationer/2013-552

2. Tämä Policy Brief on luettavissa englanniksi, ruotsiksi, tanskaksi ja islanniksi osoitteessa http://www.norden.org/en/publications/publikationer/2013-566

3. Blogi englanniksi http://sustainabilitymyths.blogspot.se/

4. Webinaarin nauhoitus https://connect.sunet.se/p6xwhdd4evj/ 


\section{Hankkeen tiedot}

\section{Koordinoija}

International Institute for Industrial Environmental Economics

Lund University

P. O. Box 196 Tegnersplatsen 4,

SE- 22100 Lund Sweden

http://www.iiiee.lu.se/

Tel: +46462220250

Faksi: +46 462220250

Oksana Mont, projektipäällikkö oksana.mont@iiiee.lu.se

\section{Tutkimuskonsortio}

Oksana Mont, Lundin yliopisto, Ruotsi

Kate Power, Copenhagen Resource Institute, Tanska

Eva Heiskanen, Kuluttajatutkimuskeskus, Suomi

Helka Kuusi, Kuluttajatutkimuskeskus, Suomi

Pohjoismaiden ministerineuvoston yhteyshenkilö

Camilla Sederholm

+358400930886

Sähköposti: camilla.sederholm@miljo.fi

www.norden.org/hkp

\section{Kesto}

15. toukokuuta 2012-15. huhtikuuta 2013

\section{Rahoitus}

Pohjoismaiden ministerineuvosto

\section{Budjetti}

PMN:n osuus 330000 Tanskan kruunua 
Ved Stranden 18

DK-1061 København K

www.norden.org

Pohjoismainen tiivistelmä

Vaikka kestävän kulutuksen politiikkaa on harjoitettu 20 vuotta (UNCED 1992), materiaalien kulutus ja ympäristövaikutukset lisääntyvät edelleen Pohjoismaissa ja Euroopassa. On epärealistista odottaa kestävän yhteiskunnan toteutumista nykyisten kestävän kehityksen poliittisten strategioiden pohjalta. Tarvitaan isoja muutoksia, ja tässä tutkimuksessa tiivistetty tutkimustieto osoittaa, että päätöksentekijöillä on suunnaton määrä mahdollisuuksia luoda myönteisiä muutoksia. Tämän tutkimuksen tavoitteena on kumota kestävää kehitystä estäviä myyttejä esittämällä tutkimustietoa kuluttajakäyttäytymisestä tehokkaiden kestävän kulutuksen politiikkojen kehittämiseksi Pohjoismaissa. Tutkimuksessa käytetään tiedon välittämisen (knowledge brokering) lähestymistapaa. Tutkimus perustuu laajaan kansainväliseen kuluttajakäyttäytymistä koskevaan tutkimusaineistoon mm. psykologian, sosiologian, käyttäytymistalouden, politiikan ja antropologian aloilta.

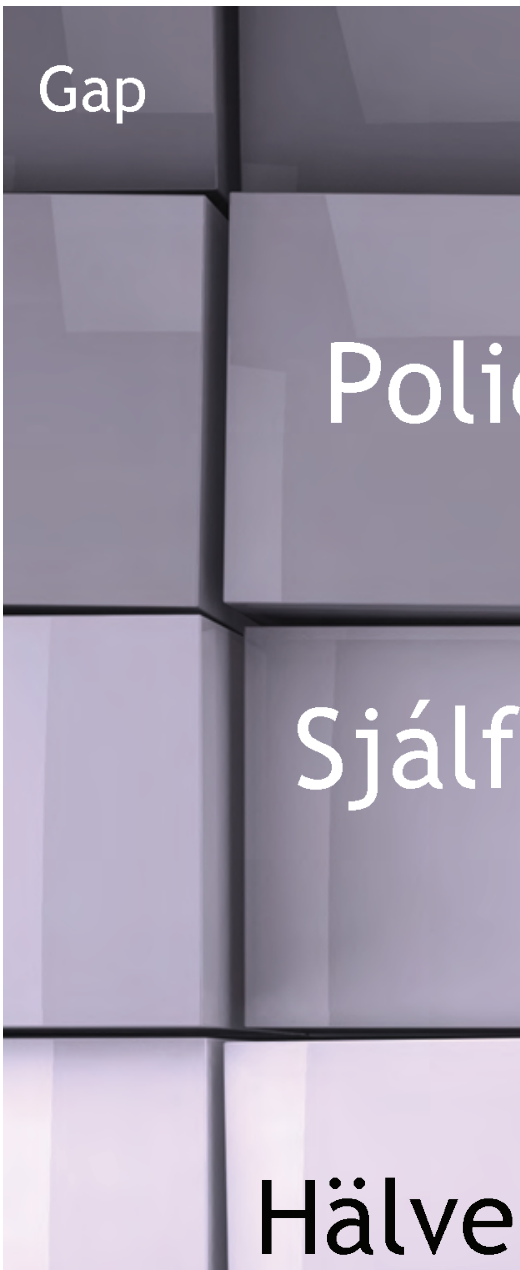

